The Chittagong Univ. J. B. Sci., Vol. 6(1 \&2):65-76, 2011.

\title{
QUALITY OF URBAN ENVIRONMENT: A CASE OF CITIZEN'S PERCEPTION IN SATKHIRA MUNICIPALITY, BANGLADESH.
}

\author{
KAZI MD.BARKAT ALI ${ }^{1} *$, MD.IQBAL SARWAR ${ }^{1}$, MORSHED HOSSAN MOLLA $^{1}$ \\ Department of Geography and Environmental Studies, University of Chittagong
}

\begin{abstract}
In this study, an attempt has been made to identify the major problems of urban environment in Satkhira Municipality. The perceptual data were collected through field survey based on structural questionnaire. It designed 100 selected respondents and framed 32 environmental variables including 3 points satisfaction index. It was observed from the study that drainage congestion is the major urban environmental problem of Satkhira Municipality and it creates a variety of physical environmental problems such as water logging, increasd soil and water salinity level, water and soil pollution etc. of the area. Because of the absence of certain urban facilities such as employment opportunity, recreational level, shortage of electricity supply (illegal connection, improper meter reading, system loss and load shedding etc.) inadequate local security, city dwellers are found to be dissatisfied. These lead to the generation of various social disorders including hijacking, vandalism and phonongraph, etc. However, there are ample scopes to develop a sustainable (eco-friendly) city keeping these considerations in mind.
\end{abstract}

Key words: Urban environment, Citizen's perception, Satkhira Municipal

\section{INTRODUCTION}

Bangladesh with a massive national population (over 162 million), has a huge urban population. Though the number of urban population is now 30 million, the level of urbanization in Bangladesh is still low in present condition (Islam 2003). The impact of urbanization in Bangladesh in terms of mass poverty, gross inequality, high unemployment, under-employment, over crowding, housing and proliferation of slum and squatters and at large deterioration in the overall environmental conditions has become the major concerns of policy issue. There are clear evidences of highly inadequate supply of clean water and unhygienic sanitation in the urban condition. High incidence of the diseases, violence, crime and social tensions are common features in towns

"Corresponding author: kbacu@ yahoo.com 
KAZI MD. BARKAT ALI et al.

and cities in Bangladesh. These are the most common sceneries in the megacity, statistical Metropolitan Areas (SMAS) and Pourashava or Zilla headquarter. The distribution of urban population in the country is uneven due to many reasons. Important reasons are perhaps located to cities and towns, various geographical factors, pace and pattern of development, development of infrastructure and communication network. The Census Commission of Bangladesh has classified all urban centers in the country into four categories the Megacity, Statistical Metropolitan Area (SMAS), Pourashava and other urban areas. Metropolitan city with population more than 10 million is termed as megacity. There is only one megacity in the country, Dhaka, had a population of 10.71 million in 2001, (Nazem 2003) statistical metropolitan areas are the city corporation and their adjoining areas with urban characteristics. On the basis of this definition BBS 2001, identified three metropolitan cities in the country. Namely Chittagong $(3.38 \mathrm{~m})$, Khulna $(1.34 \mathrm{~m})$ and Rajshahi $(0.7 \mathrm{~m})$. These three cities had total urban population of 5.42 million or about 19 percent of the national urban population in 2001. The next category of towns is Pourashava. The areas declared by the ministry of local government, rural development and cooperatives as municipal town or Pourashava have the formal urban status with local governments during the census of 2001. There were 223 Pourashava in the country and a total about 9 million or $30 \%$ of the national population (Nazem 2003). Other urban areas are Upazilla headquarters or big market places in the rural areas which have not yet been declared as Pourashava during the census operation. According to population census-2001, urbanization levels in Bangladesh is still relatively low (23.1 percent in 2001) and it up and down by the criteria of cities, (i.e. population rate, urban environment, utilities provide and availability etc). Dhaka city is $90 \%$ level of urbanization on the other hand Satkhira Municipal city is $7.2 \%$ level of urbanization (Nazem 2003).

The quality of urban environment depends a great deal on the quality of essential infrastructural and their appropriate management. Utility services like sanitation, sewerage, drainage, drinking water supply, garbage disposal, electricity, gas, and fuel for cooking are important physical infrastructure for maintaining the urban environmental quality (Islam et al. 1997). Environmental fibers are being continually strained due to population explosion. As the population grows the demand for different types of urban services and facilities also increases (Hossain 1995). The study of environmental perception seeks to focus on specific aspects the environment that are related to man's welfare (Beehtel 1979). In the modem urban planning, urban decisions are made from 
QUALITY OF URBAN ENVIRONMENT: A CASE OF CITIZEN'S PERCEPTION IN SATKHIRA MUNICIPALITY, BANGLADESH.

local level community participation and in that case citizen's perception in every aspects of urban life is most important, citizen's perception of various environmental elements, such as air, water and sanitation, need to be properly studied and know, such response is demand useful for understanding urban problems and think about solution of such problems (Islam and Hossain 1999-2000). An obvious impact of this increase in urban population has been the increased demand for land housing in all urban area especially Megacity, Statistical Metropolitan area and Municipal town and other urban areas. The satkhira municipal town faces various, physical, neighbourhood and socio-cultural problem location ally Satkhira sadar is busy for shrimp farming as well as fish production in (i.e. inland or, Marine) south west Bangladesh and it stands near to the sundarbans on Bay of Bengal. Due to gradual increase of urban population the facilities are over streams. This deteriorates the quality of intra-urban environmental component.

\section{Study Area}

Satkhira is a district town. It is situated in Khulna division. It is extended from $21^{\circ} 20^{\prime} \mathrm{N}$ to $22^{0} 50^{\prime} \mathrm{N}$ latitude and $89^{\circ} 00^{\prime}$ to $89^{\circ} 20^{\prime}$ East longitude. Satkhira district is with an area of $3858.3 \mathrm{sq} \mathrm{km}$. On the other hand Satkhira Sadar Upazila is with an area of $400.82 \mathrm{sq} \mathrm{km}$. It is small Municipal town centers on the south west borderer of Bangladesh. It is bounded by Kalaroa Upazila on the north, Debhata and Assasuni Upazila on the south, Tala Upazila on the east and west Bengal of India on the west (Ashraf 2003). 
KAZI MD. BARKAT ALI et al.

MAP: LOCATION OF THE STUDY AREA

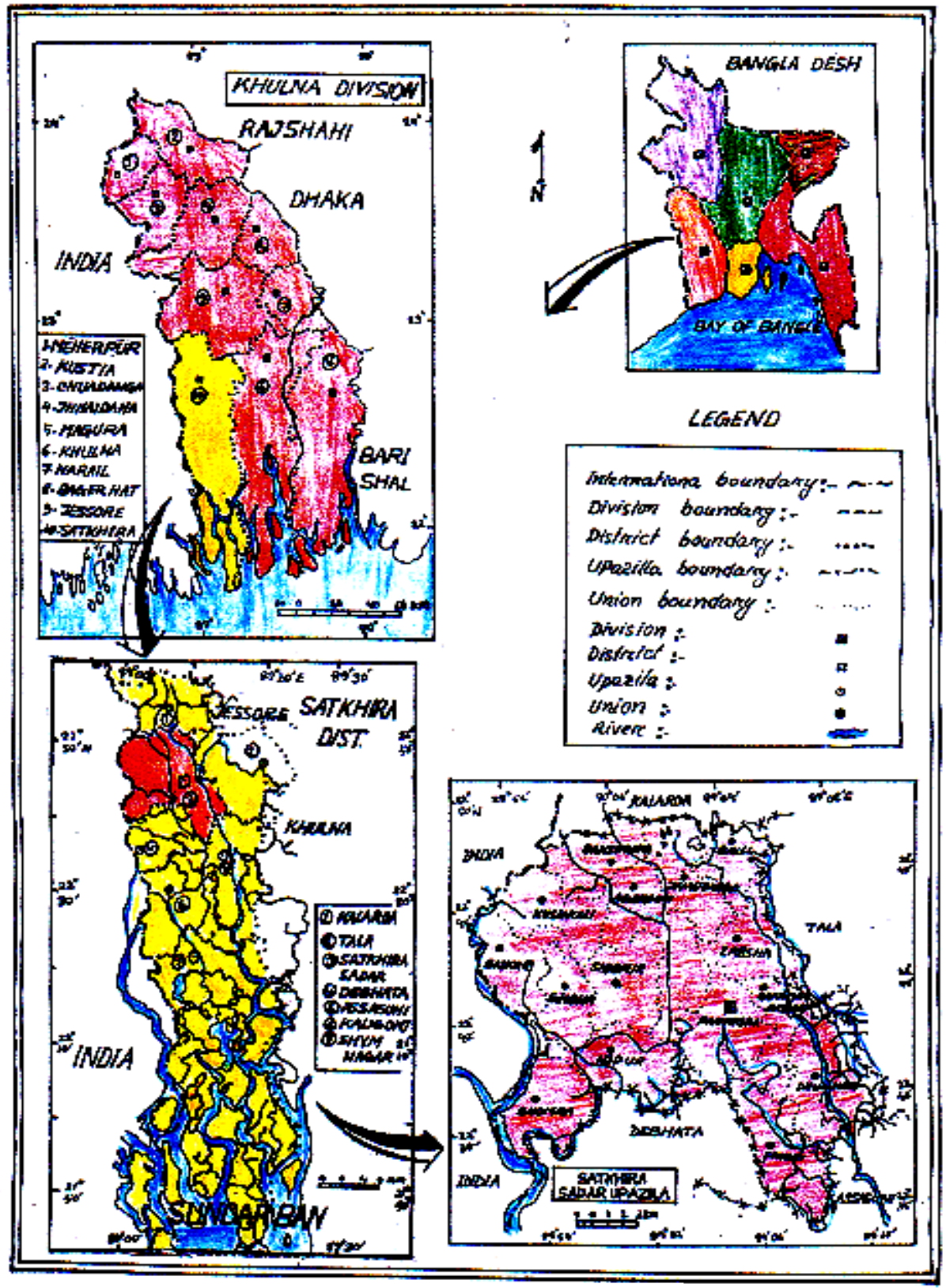

Source: Redrawn Bangla Pedia, 2003 
QUALITY OF URBAN ENVIRONMENT: A CASE OF CITIZEN'S PERCEPTION IN SATKHIRA MUNICIPALITY, BANGLADESH.

Satkhira subdivision was established in 1861 under Jessore district. It was included into Khulna district in 1882. The subdivision was turned into a district in 1984 as a result of the administrative decentralization. Satkhira municipal town consists of 01 ward and 31 Mahallas. The total area of the town is $27.84 \mathrm{sq} \mathrm{km}$. with a population about 86372 (in 2001). Male are 51.75 percent and female are 48.25 percent and the population density is 3102 per sq $\mathrm{km}$. The town is poor in its literary tradition and culture. Most of the populations are businessmen and services holders. Thirty percent of the populations earn their livelihood from agriculture. The base of industrial of the town is very weak. The town is run by the municipal and district administration. The municipal administration of the town consists of one elected chairman and I elected wards commissioners and 3 elected women wards commissioners.

The objective of this paper is to determine the quality of urban neighbourhood environment as perceived by the residents of Satkhira Sadar.

The specific objectives are;

1. to know about the urban environmental problem that may exist in the study area; and

2. to determine the level of satisfaction of urban environment as expressed by the residents of the study area.

\section{MATERIALS AND METHODS}

Investigations of urban environmental problems are based on perceptual as well as factual data. These factual data have been collected from various sources. Secondary data were collected from the Municipal office of Satkhira Sadar. The perceptual data were collected through structural questionnaire survey; main environmental problems have been identified from the citizen's perception. Finally, the main problems were identified by the citizens that's were further analyzed for the evaluation of environmental quality. A questionnaire was designed taking 40 questions against the 30 environmental variables (Table 01) on 3 points of satisfaction scale. Among the 30 variables, 7 variables are related to physical environment and 7 variables are related to neighbourhood /social environment. Finally 120 questionnaires were surveyed. 
KAZI MD. BARKAT ALI et al.

TABLE 1: MAJOR URBAN ENVIRONMENTAL VARIABLES

\begin{tabular}{ll}
\hline Environmental types & Major environmental variables \\
\hline Physical environmental & $\begin{array}{l}\text { Tidal food, salinity, saline water Intrusion, air } \\
\text { quality, water bodies, vegetation coverage and noise } \\
\text { factor. }\end{array}$ \\
Neighbourhood/social & Water supply, gas supply, electricity supply, \\
environmental & sanitation facilities, telephone performance, garbage \\
& disposal system, drainage condition, number of \\
& Parks/Playground, local security, law and order \\
& situation, transportation system. Traffic \\
& management, housing. Road network, cleaning and \\
& Maintenance, Recreational facilities, slums and \\
& squatters, educational facilities, community \\
facilities, medical facilities, employment facilities, & postal service, community action programs and \\
mastan (Musclemen) problem.
\end{tabular}

A random sampling technique has been adopted to administer the all questionnaire survey. To determine citizen's level of satisfaction a satisfaction index $\left(I_{s}=f_{s}-f_{d} / N\right.$, Where, $f_{s}=$ Number of satisfied Respondents, $f_{d}=$ Number of Dissatisfied Respondents and $\mathrm{N}=$ Total Number of Respondents) (Yeh and Lee 1975) were applied. For this satisfaction index, $I_{s}=+1$ means highest level of satisfaction and $I_{s}=-1$ means highest level of dissatisfaction. In this respect, negative index of satisfaction was taken to identify as an environment problem.

\section{RESULTS AND DISCUSSION}

Characteristics of the respondents

Male respondents were the higher percentage (57.40\%) compare to the female $(42.40 \%)$ respondents. Young as well as middle aged (18-45) age group) people were the maximum respondents (79.25\%) in this study and rest of respondents are (45-55) aged group. Among the total respondent 5.86\% passed the SSC and HSC and $18.5 \%$ is primary VI to X level of education. A modest percentage $27.62 \%$ of the respondents passed Graduate. Most of the respondents are engaged in business and service activities (27.78\% and 25.93\%). 
QUALITY OF URBAN ENVIRONMENT: A CASE OF CITIZEN'S PERCEPTION IN SATKHIRA MUNICIPALITY, BANGLADESH.

\section{Major urban environmental problems}

As mentioned earlier a structural question was incorporated in the questionnaire to identify the major/main environmental problems in Satkhira Municipality and rank them from the total environmental problems as expressed by its citizens. Among the ten main problems, eight have been identified as neighbourhoods environment related out of all drainage congestion is a neighbourhood environment ranks the population and salinity intrusion a physical environment ranks the thinking problem. Main physical problems are salinity intrusion and water pollution as Satkhira Sadar is in the western coastal municipality of Bangladesh. Tidal water on easily enter the cannel, khal (nala), River in the city and lack of upper stream flow water due to saline water are not to remove rapidly,

\section{TABLE 2: MAJOR URBAN ENVIRONMENTAL PROBLEMS}

\begin{tabular}{lcccc}
\hline Environmental Problems & Frequency & Percentage & Rank \\
\hline 1. Drainage congestion & 39 & 24.37 & 1 \\
2. Waste problem & 25 & 15.62 & 2 \\
3. Salinity Intrusion & 20 & 12.5 & 3 \\
4. Water pollution & 17 & 10.62 & 4 \\
5. Fuel crisis & 15 & 9.37 & 5 \\
6. Lock of recreational center & 13 & 8.12 & 6 \\
7. Hijacking & 11 & 6.87 & 7 \\
8. Narrow road & 9 & 5.62 & 8 \\
9. Electricity & 6 & 3.75 & 9 \\
10. Phonograph & 5 & 3.12 & 10 \\
Total & 160 & 100.00 &
\end{tabular}

Source: Field survey 2007

As a result, saline level of the areas is increasing day by day and ultimately, increase water, soil $\mathrm{pH}$ and salinity level due to polluted soil and water quality of Satkhira surrounding area. On the other hand neighbourhood problems are the very extreme in this area. Lack of municipal initiative is another problem in this area. There is no identified dustbin people throw waste near the road, drain and open space. As a result drain is filled up with various types of wastes, creates odor problems and creates drainage congestion. As a result tidal saline water stops of the city or surrounding area. It is indirectly the main cause of increasing a 
KAZI MD. BARKAT ALI et al.

salinity rate. Also lack of law and order, Hijacking and phornograph is another neighbourhood problem in the area and no leisure or recreation center here. Fuel and electricity crisis is also another main problem of urban inhabitants.

\section{Physical environmental problems in Satkhira municipality}

An urban environmental problem has been measured from value of satisfaction index. From the satisfaction index, variables have been taken as problems which showed the negative index of satisfaction. Among the seven physical environmental variables (05) five showed the negative index of satisfaction. According to rank, these are salinity intrusion, water pollution cutting vegetable coverage. Satkhira district is situated on the western coastal zone of Bangladesh. Geographically this area is flood and disaster free. But now-a-days tidal water enters the area and it is not easy to remake rapidly due to fillup drainage system. Damping waste, irresponsibility of municipal initiative, lock of upper stream flow and entering saline water is also static. As a result soil and water salinity level are on increase, ultimately polluted soil and water quality. Saline intrusion is the main causes of soil and water pollution. Noise pollution is the fourth of the physical environmental problems of this area. Basically two types of noise pollution are occurred in urban life, these are inside (loud speaker, Radio TV sound etc) and outside (making for publicity, advertisement pedlar shouting etc.)

TABLE 3: PHYSICAL ENVIRONMENTAL PROBLEMS IN SATKHIRA MUNICIPAL CITY

\begin{tabular}{|c|c|c|c|c|}
\hline 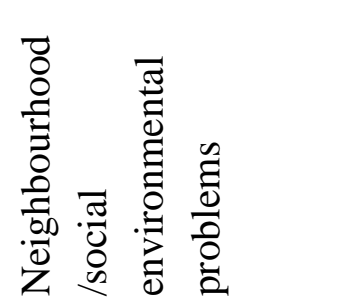 & 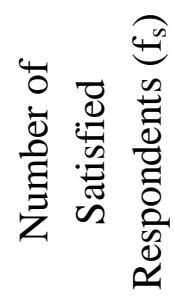 & 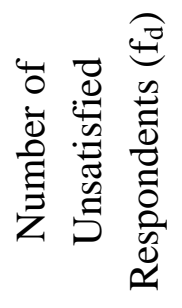 & 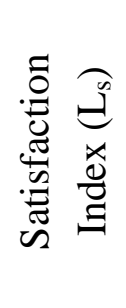 & 華 \\
\hline 1.Salinity Intrusion & 23 & 89 & 0.412 & 1 \\
\hline 2. Water Pollution & 38 & 67 & 0.181 & 2 \\
\hline 3. Soil Pollution & 29 & 58 & 0.181 & 2 \\
\hline 4. Loss of vegetable & 49 & 75 & 0.162 & 3 \\
\hline 5. Sound Pollution & 42 & 65 & 0.143 & 4 \\
\hline
\end{tabular}

Source: Field survey 2007

Note: Rank indicates severity of the problems 
QUALITY OF URBAN ENVIRONMENT: A CASE OF CITIZEN'S PERCEPTION IN SATKHIRA MUNICIPALITY, BANGLADESH.

Inside sound problem is a common phenomenon in urban life in every residential area. On the other hand, outside sound problem has been seen in the shopping, market areas, central city for publicity and advertisement purposes. At times, outside problems have also been created in the residential area for loudspeaker in wedding ceremony various social occasions. Satkhira Sadar and the Surrounding areas also faces fuel crisis. There is no gas provider in this area; city dwellers use gas cylinder, wood fuel and illegal electricity connection. That time pressure creates of wood as a result vegetation specie one cut down rapidly for fuel purpose.

\section{Perceived neighbourhood/social environmental problems in the municipality area}

Among 25 variables in neighbourhood/social environment 12 variable have shown negative index of satisfaction According to rank, these are the supply of electricity, recreational facilities fuel crisis, drainage congestion, hijaking waste problems, employment facilities, health facilities, local security, phonograph, narrow road and poor communication (Table 04). Among the neighbourhood environmental problems, supply of electricity (-0.431) has showed the height negative value of satisfaction index. Shortage of supply and load shedding is a daily matter of this area. Nationally, electricity crisis is everywhere but in this area, system loss and illegal uses of (cooking purpose) electricity are the main problems. Recreational facilities $(-0.381)$ was placed in the second position according to negative index of satisfaction. Recreations facilities are most important for urban dwellers, recreation facilities are not only shrinking because of the increase of population but also provide healthy mind and life. Unfortunate no recreational facilities exist here. Fuel crisis $(-0.312)$ placed as the third position according to negative index of satisfaction level Satkhira Municipality, not being connected to piped gas supply. So depending on different kinds of fuels (gas cylinder, kerosion, Fire wood, electricity) for cooking the illegal use of electricity for the purpose of cooking is most widely carried out in this area. 
KAZI MD. BARKAT ALI et al.

TABLE 4: PERCEIVED NEIGHBOURHOOD /SOCIAL ENVIRONMENTAL PROBLEMS IN THE MUNICIPAL CITY AREA

\begin{tabular}{|c|c|c|c|c|}
\hline 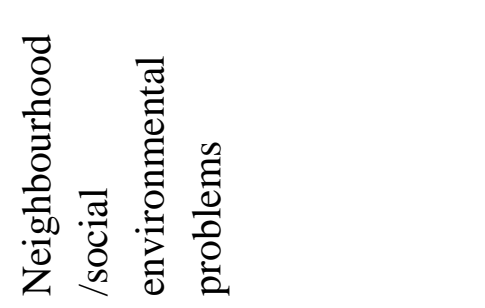 & 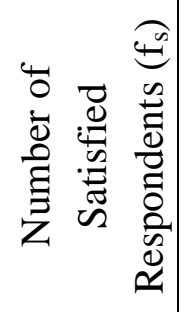 & 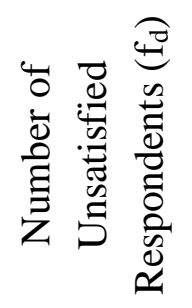 & 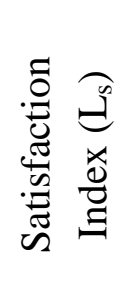 & 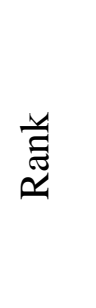 \\
\hline 1.Supply electricity & 7 & 76 & -0.431 & 1 \\
\hline 2. Recreational facilities & 12 & 73 & -0.381 & 2 \\
\hline 3. Fuel Crisis & 32 & 82 & -0.312 & 3 \\
\hline 4. Drainage congestion & 27 & 69 & -0.262 & 4 \\
\hline 5. Hijaking & 36 & 78 & -0.262 & 4 \\
\hline 6. Waste problems & 10 & 50 & -0.25 & 5 \\
\hline 7. Employment facilities & 35 & 72 & -0.231 & 6 \\
\hline 8. Health /Medical facilities & 28 & 62 & -0.212 & 7 \\
\hline 9. Local security & 19 & 53 & -0.212 & 7 \\
\hline 10. Phonography & 35 & 59 & -0.15 & 8 \\
\hline 11. Narrow Road & 28 & 49 & -0.131 & 9 \\
\hline 12. Poor Communication & 30 & 51 & -0.131 & 9 \\
\hline
\end{tabular}

Source: Field survey $2007 \quad$ Note: Rank indicates severity of the problems

Drainage congestion and Hijacking are independent problems. In this city drainage congestion (-0.262) is one of the most important neighbourhood problems. Narrow drain, drain fillup of municipal waste, household waste throwing the drain and fillup by mud, is the main problems of drainage congestion. Hijacking is a common phenomena in city areas. Local people are always scared about hijacking. It occurs in the night when people return his/her resident. Lack of local security is the main cause of hijacking. Waste problem (0.25) placed the fifth position according to negative index of satisfaction. Disposal of waste is really a problem for Satkhira Municipality dwellers due to its unsatisfactory management system. There is no is identified dustbin; people are throwing waste in the drain, road side, open or vacant land and book side of House due to create odor problem everywhere some unplanned dustbin are seen on the road in the city. No municipal initiatives to clean the area. Condition of 


\section{QUALITY OF URBAN ENVIRONMENT: A CASE OF CITIZEN'S PERCEPTION IN}

SATKHIRA MUNICIPALITY, BANGLADESH.

employment facilities is not so good because there is no large industry here, is located export one textile, some ice factory fish processing unit and some cottage industry are rising, Most people are engaged in agricultural activities, some are in business and service. So, majority of the urban poor are day labor or labor of shrimp farming. Health facilities have not been grown according to public demand. In recent time, some private clinics and hospital had been set up which are affordable to the high income group of people. Sometime, Patients emergency shift to Dhaka or another place. Phornography is the major cultural problem of city area. The show of some obscene movie (Tea-set Stall, normal restaurant \& cinemas hall, lack of law and order situation as well a doubtful role of police force is the main course of this problem. Narrow road and poor communication are also independent. Unplanned structure is the common phenomena of all urban city of Bangladesh. Road network of Satkhira Municipality area is very narrow and existing road or covered illegal shop, seasonal mercentizer, illegal perking of rickshaws .Poor communication is related to road, telephone facilities of the city. Narrow road but over crowded vehicles, telephone performance is very poor because TNT board are not to provide new connection of the dwellers in the legal.

\section{CONCLUSION}

The study illustrates the various states of the existing urban environmental aspects. Drainage congestion received the highest rank and on the other hand salinity intrusion was perceived as the highest rank among the physical environmental problems. Seventeen variables out of thirty two (near about 50\%) were identified as urban environmental problems. According to negative value of satisfaction index most vulnerable variable are supplies of electricity, recreational facilities, fuel crisis, drainage congestion, hijacking, waste problem, employment facilities, health facilities, Local security, phornography narrow road, poor communication in the neighbourhoods environmental. On the other hand salinity intrusion water pollution, soil pollution, sound pollution, deforestation were identified as the physical environmental problems in the city. Satkhira Municipality area is a rising urbanized and shrimp prospective area of Bangladesh. Also municipal authority unfortunately not has taken any planned step in this town. Various cities of Bangladesh physically and socially have been already crossed well beyond its threshold limits and the city dwellers are susceptible to serious environmental concerns. The present study shows that the process of such degradation has already been started in Municipality of Satkhira. If it ensures that Sustainable urban development would require both planning and 
KAZI MD. BARKAT ALI et al.

its implementation, neighbourhood urban local government leadership with vision with a commitment for planned urban development. Dedicated, honest and skilled planning implanting can ensure future environmental friendly and ecologically sustainable Satkhira Municipality.

\section{REFERENCES}

ISLAM, N., KHAN, M. M. AND CHOWDHURY, A.I. 1998. Urban planning and development process in four secondary towns in Bangladesh, in Nazrul Islam (eds.), Recent urban studies, Bangladesh, pp. 6-23.

ELAHI, K.M. AND ALAM, M.S. 1998. Urbanization and physical environmental: A study on the Dhaka urban fringe in Nazrul Islam (eds.), Recent Urban Studies, Bangladesh, pp. 24-44.

ISLAM, N AND HASAN, S.R.1999-2000. Urban environmental quality: resident's perception in Sylhet city, The Journal of Bangladesh National Geographical Association 27-28 (1-2):11-20

MURTAZA, M.G. 2002. Environmental problems and citizens perceptions and a study of Khulna city, Bangladesh, The Journal of Bangladesh National Geographical Association. 21-26 (1-2) : 31-42

NAZEM, N.S. 2003. Urban growth and urbanization in Bangladesh: interpretation of Census 2001, CUS desk report, CUS Bulletin on Urbanization and Development: 45:.9-12.

RAHMAN, M.M 2002. Urban environmental problems in metropolitan Chittagong: A case of citizens perception, CUS bulletin on urbanization and development: 42:40-43.

SARWAR, M.I. 2004. Perception of urban environmental: A case Study of Chittagong Metropolitan, Unpublished M S thesis, Department of Geography and Environmental Studies, University of Chittagong, $136 \mathrm{pp}$

SARWAR, M.I AND CHOWDHURY M.A.T 2008. Quality of urban neighbourhood environmental: A case study of resident's perception in Chittagong city, Bangladesh, the journal of Geo-Environmental 8:30-40.

Manuscript received on 14.07.2011; Accepted on 07.07.2012

The Chittagong University Journal of Biological Sciences, Vol. $6(1 \&$ 2). Page No. 